2015-10-15

\title{
Sites of dereliction: beginnings and allies of performance
}

\author{
Smith, Phil
}

http://hdl.handle.net/10026.1/12021

10.1080/13528165.2015.1049038

Performance Research

Informa UK Limited

All content in PEARL is protected by copyright law. Author manuscripts are made available in accordance with publisher policies. Please cite only the published version using the details provided on the item record or document. In the absence of an open licence (e.g. Creative Commons), permissions for further reuse of content should be sought from the publisher or author. 
Accepted manuscript date accepted: 28.1.15

No embargo date

Sites of dereliction: beginnings and allies of performance

Phil Smith (Plymouth University)

School of Humanities \& Performing Arts

Plymouth University

Drakes Circus

Plymouth

PL4 8AA

philip.smith@plymouth.ac.uk

mytho.smith@btopenworld.com 


\section{Abstract}

This paper charts a changing relationship to ruins over fifteen years of making sitespecific performance. It looks at three sets of ruins (a nineteenth-century water tower and a chapel and almshouses, both of medieval origins) and records how they each acted as the beginning of three separate post-dramatic performance projects. By revisiting and walking between the three sets of ruins, the author tests his own changing understanding of their materiality: from inert properties waiting for invasive or re-compositional acts to unfinished and vibrant materials actively recomposing themselves as allies in resistance and 'slow revolution'.

Keywords:

Ruins, site-specific performance, walking, vitalism, détournement 


\section{Sites of dereliction: beginnings and allies of performance}

Phil Smith

Ruins are different from 'ruins'. Moving about in their contrasting sites, exploring them or making performances for them, over the last decade or so has changed how I understand what they are, what they do and how they are with each other.

'Ruins' are what remain when ruination is temporarily and superficially removed from ruins; those strange places where the grass is mown in the moat, where visitors largely ignore the materials in their hunger for signs, where wooden walkways are constructed for apparent fear that folk might become infected by the thirteenth century.

Where ruination prevails materials can fare better and more eloquently. In Gloucester (UK), a five storey Boots store can be observed (on special tours) balanced on a steel girder that in turn rests on the foundations of the Roman city wall. The past holds up the present, the twentieth-century store continues to test the performance of Roman engineers. The past supports and dialogues with the present, but it also 'holds it up' in the sense of delaying it, placing a torque upon its hypermodern velocities, eradications and rapid exchanges of things and images.

Despite the quotation marks, ruins are no more authentic or legitimate than 'ruins', nor 'ruins' any less performative or vital than ruins; they are both layers that exist at different strengths and thicknesses in almost any site of ruination. Given the mythogeographical principle of multiplicity, my interest in these sites is not in privileging one of their performances over the other, nor in claiming priority for their particular tension over other tensions, but in exploring the effects on a visitor when subjected to (or subjecting themselves to) both the excessive stories and 
atmospheres released by 'ruins' and the intense encounter with the textures, vitality and resistant 'thingness' of materials in ruination.

\section{St Loye's}

In September 2013 I arranged to begin a walk with Clare Bryden, a blogger on religious and ecological affairs, at the ruins of the chapel of St Loye on Rifford Road in Exeter (UK). Roofless, with three remaining walls mostly of local red sandstone (presumably from nearby quarries where the stone was laid down in 300 million year old Permian deserts), the ruins of St Loye's chapel are surrounded by 1930s council housing built right up to its old walls. Tarmac paths pass on two sides of the chapel and grass lawns inside and outside are kept mown, with token ornamental shrubs planted on one side.

This walk with Clare was an early venture of a new project (ongoing in 2015) exploring performance or dance that might develop an inner or subjective life using what I was describing at the time as 'uncertainly sacred places' or 'pseudo-sacred spaces'. I was seeking out sites whose sacredness might be seen as accidental, eroded, oblique, secular, imagined or misunderstood, equally hospitable to those with or without a religious or occult belief; finding such places was one of the purposes of our walk.

The chapel of St Loye was established in the fourteenth century. By 1607, however, a document records that half of the building was being let as a dwelling, and soon after the whole of it was lost to religious worship and later was given over to use as stables. There is an irony here, for Saint Loye (sometimes Eligius) is the patron saint of farriers, reputed to have shoed a difficult horse by miraculously removing the horse's leg, shoeing the amputation, and then reattaching the leg.

Despite the appealing excess of this story (with its resonance for a site that had been halved, de-sacralised and then 'restored' to a ghost of its first identity; the nearby granite cross and the tall lancet windows define the site even for a casual passerby as religious) and the exotic origins in ancient, prehistoric deserts of the building's stone, as I waited for Clare I found it hard to connect any narrative to the place as I was experiencing it. I felt the glances of passersby, somewhere between suspicion 
and disinterest, as I examined intensely the materials of the chapel; my activity perhaps at odds with this now everyday obstacle on a 'cut through'. The ornamental borders around it were cursory and the conservation and privileging of ecclesiastical elements strangely half-hearted; the place hovered uneasily between ruins and 'ruins'. I discreetly pressed my body to its walls without much affect, struggling to connect to the site, to understand it, to feel any integral ambience or sharp tensions there.

My photographs show that I was attending most to the juxtaposition of modern bricks with the chapel's sandstone, and the framings of the 1930s houses in the lancet windows; 'things in ruins.... rebuke the way things are supposed to assume a position in regimented linearity' (Edensor 2005: 115). Not only were the materials of the chapel ruined, but also the space that had once set it apart in sacredness; the chapel enacted hybridity, while window spaces once intended for letting light in now invited my looking out to back gardens, patios and frosted glass. I photographed the sky through the spiders' webs in heavy railings set between the modern houses and the medieval stone cross, recording in my notes that 'on my way, on the bus, i (sic) had read (from Blake's The Book of Urizen): "Where ever the footsteps of Urizen/ Walk'd over the cities in sorrow./ Till a Web, dark \& cold, throughout all.... twisted like to the human brain./ And all call'd it The Net of Religion".' However, rather than becoming trapped, willingly or otherwise, in a Net or Web of meanings, I was being invited by the ruins to see through one.

After leaving St Loye's chapel, Clare and I traversed the suburbs of East and North Exeter. On our way to treading an old parish boundary out of suburbia and over fences and through brambles, and then trespassing in search of 'Fairy Dell', we found a portion of a fake 'stone circle', about a tenth of the circumference, ornamenting a children's playground. Just as the windows of St Loye's were framing modern materials and intervening in the act of seeing, this partial circle of stones implied completion (or traces of any imaginary ruination) in the surrounding streets. Clare used Google Maps to plot the finished circle; implying stones eerily rising in back gardens, living rooms and pavements, so oddly transforming the meaning of the place that I wondered about the feasibility of making a project with the residents to install such ludicrous stones. 
In my notebook I had written of the fake circle: 'A very thin experience? Can this be utilised and developed? .... using fakery knowingly as 'another authenticity'? Creating actions, meditations, inner-actions for these spaces?' Sharing with the chapel a lack of powerful affect and given the ambiguity of their materiality/fictionality (the 'ruining' of the fake circle being itself a fabrication), the absence of actual ruins generated a kind of shadow presence, an airy, tentacle-like reaching out to the surrounding streets. The tension between the absurdity of the circle's fakeness (devoid of any apparent local context) and the solidity and yet incompleteness of its construction was potent and active.

\section{$\underline{\text { Ruins as vital things }}$}

Though ruins are often distinctively bordered and signed, these demarcations do not always affect their circulation in the currency of things; they do not, simply by being ruins, especially resist commodification or appropriation to spectacle. Within the dromology of a hyper-connected information-based society even ruins can be 'conceive[d] of... not as objects qua objects, but as instantiations, as search-hits in a universe of possible objects' (Sterling 2005: 50); a characterisation that can be internalised so that when an object is in our proximity its 'approach is not simply about the arrival of an object: it is also how we turn toward that object' (Ahmed 2006: 2). In other words, ruins, despite their apparent material recalcitrance, are at least partially defined by our relation to them, and, in a hypermodern context, that relation can be one of an active consumer choosing a comforting or compliant image.

Against such trends, tending to privilege theories of representation over those of being, leaving things 'pacified, retreating to an exterior, silent and uniform world of 'Nature" in which '[M]atter is deemed 'indifferent' in the most literal sense: it qualifies as matter just to the extent that it instantiates universal laws' (Henare, Holbraad \& Wastell 2007: 9), I have adopted for my walks certain ideas derived at least in part from 'material vitalism'. These privilege 'the negative power or recalcitrance of things.... [as well as] a positive, productive power of their own' (Bennett 2010: 1) and celebrate performance-like moments 'when the object becomes the Other, when the sardine can looks back, when the mute idol speaks' (Mitchell 2005: 156). 
So, even when I may not be experiencing a site as powerfully affecting, I still acknowledge its capacity to form my behaviour rather than my behaviour forming its capacity. At the chapel of St Loye, although I struggled to understand clearly or experience distinctly its meanings, the ruins (by the ruination of its windows and the intrusion upon its former sacred set-asideness) framed and directed my looking and informed it with hybrid meanings.

\section{$\underline{\text { The Fall }}$}

In 2007, I set off one morning with fellow Wrights \& Sites member Simon Persighetti with the intention of spending half a day per week for a year enacting some sort of ambulatory performance on the streets of Exeter. We had called the project Relics and Processions. On that first morning we were passing through a lane in the centre of the city, recently re-opened as part of the new Princesshay shopping centre. Marked on eighteenth-century maps as 'Egypt' (a name no local historian has yet been able to explain) the developers had rationalised the name as 'Egypt Lane'.

The lane passes between a former bank, now converted to retail and residential use, and the ruins of the fifteenth century St Catherine's Almshouses, of its chapel, and of an abutting inn that had once been a canonry. Given the abject state of the ruins, one might assume a similar long-running history of use, conversion and dilapidation to that at St Loye's; in fact the buildings were in continuous use, despite a latenineteenth-century renovation and change from almshouses to Salvation Army hostel, until 1942 when Luftwaffe bombs and then the actions of the city council, who in an embrace of the modern refused to restore bombed buildings of historical significance, began and then intensified their ruin. 'Making safe' the wrecked building in 1943 the council removed much of what was left, lowering walls that still reached to roof level.

As Simon and I made our way up Egypt Lane a middle-aged woman approached from the opposite direction. Somehow losing her balance she stumbled onto the short sloping path into the Almshouse ruins, accelerating through the empty sandstone doorway and crashing onto the re-floored ruins. Simon and I rushed to her aid, helping her to her feet. She began immediately, with great intensity, intimacy 
and velocity to speak about the recent death of her mother and of her feelings for her. It seemed that plunging from the modern paving of the renovated Princesshay into medieval ruins, from the busy rush of shoppers into the quiet of the ruins ('the stillness of ruins provokes a comparison with the fast urban world outside' [Edensor 2005: 126]) had triggered an almost violent reversion to the past, her own immediate past, to a painful nostalgia, to an overspeaking and excessive confidence in strangers; 'a moment when the past is recognised in the present as a ruin that was once desired' (Rendell 2011: 44). Within moments the woman 'regained her composure', visibly adjusted her physical posture, turned and almost ran from us, disappearing up the lane into the crowds of shoppers and the shiny glassiness of the new Princesshay.

After our encounters that morning, rather than creating the processions we had planned we decided to walk repeatedly a single street (Queen Street) and allow ourselves to entangle with its performances as a means to making our own. Over the course of the project (it lasted between 2007 and 2010 when we created a two hour performance walk entitled $A$ Sardine Street Tour [Crabman \& Signpost 2010]), we experienced a number of similarly excessive and emotional encounters associated with ruins of different kinds, including a cook who insisted we join him to visit the eighteenth-century prison cells beneath the Rougemont Hotel kitchens, a young man who recounted being chased up Queen Street by a poltergeist from the cellar of the Well House Tavern in Cathedral Close and our arrival outside the front gates of the Royal Albert Memorial Museum just as the museum's director was locking them for three years of renovation.

\section{Excessive spaces}

The ruins with which Simon and I entangled over three years often shared excessive, compromised and performance-like qualities. The museum, marked for destruction by Thomas Sharp the post-war planner of Exeter (following the same ideology as that which saw the St. Catherine's Almshouse ruins substantially reduced), houses the skins of animals shot by the hunter C. V. A. Peel, author of the fascistic failed-utopia novel 'The Ideal Island' (1927). On the morning, we came across the director locking the museum, Simon was carrying a copy of another of 
Peel's books and from it he read to her Peel's own account of killing, and then eating the heart of, the elephant whose skin is displayed within the museum; a revelation to the director.

The cellar of the Well House Tavern contains the remains of a medieval garderobe, a well proposed in tourism literature as 'Roman', modern metal casks of beer, and what appears to be a human skeleton in a glass case exhibited under the rubric 'birth is the first step unto death' (often cited on my walking performances); tests by archaeological pathologists from the University of Winchester have revealed that the skeleton is composed of the bones of two people, a young man and a middle-aged woman, meshing neatly with the local legend of a romantically involved nun and monk throwing themselves down a well in Cathedral Close.

A previous visit to the lower levels of the Rougemont Hotel, with its abandoned subterranean night club, had included, farcically, our guides describing what was clearly a modern broom cupboard as an eighteenth century prison cell; this time we were shown the real thing and, appropriately, our photos were full of 'orbs'.

The ruins adjacent to Egypt Lane have a similar dynamic to such excessive places; material and curatorial confusions release excessive narratives there. The city council's 1943 assault and a 1980s excavation revealing parts of a layer of Roman mosaic, quickly removed to the museum. The floor of the ruins is now host to works of 'public art' including arched Perspex cases ghosting absent doorways and containing artefacts excavated from the ground of the site. As well as the pottery fragments and nineteenth-century bottles, there is also a Cola can; I remember hearing, at the time of the installation, that the can had provoked comments about its inappropriateness.

It might seem commonsensical that the eroding away or smoothing of complex materials and shapes, the 'making safe' of structures, the cleaning, ornamenting and regular maintaining of sites and the institution of authoritative information signs would lead inevitably to a simplification of ruins, closing down their meanings and the dynamism of their materials; a 'purification of space.... [with] distaste for or hostility towards the mixing of unlike categories' (Sibley 1988, 409) as a result of which a site could be 'threatened not by destruction but by preservation - the ruination of the ruin' (DeSilvey 2014: 87). However, such processes and interventions, even when 
intended as disciplinary or founded on a conspiracy between manager and visitor to ignore (like that between an audience and onstage stage hands), often add to the vibrancy of these sites.

Despite the waning of former practices of integrating ruins with new buildings - the Greyfriars ruins at Dunwich once contained a town hall, gaol and private house, the ruins of Bungay Castle a large private house, the small church at Covehithe is built within and from the ruins of its larger predecessor, and even Stonehenge (all UK) in the 1920s had its own abutting 'tea shoppe' and pig farm - attempts to discipline and homogenise sites create their own hybrids and montages. Repairs can function as a kind of commentary by juxtaposing processed materials with no longer available ones, local with generic ones, and disruptions to patterns that highlight the patterns themselves. Signage, particularly outside, can become rapidly subject to ruination, conjuring ironies and startling juxtapositions: 'total order is an impossible goal, and new practices and groups are always coming into existence.... to disrupt dreams of a regulated world' (Edensor 2005: 60). At St Catherine's the artist's illustration of the depredated Roman mosaic has itself begun to erode; the once bright red Cola can is now as faded as the controversy it first provoked.

\section{Thicket}

The last of the three ruins to be discussed here, and the first to be visited, is a nineteenth-century water tower built to serve Exeter City Asylum (opened in 1886 as 'Exeter Asylum for the Insane', it was closed in 1987 and later converted to private residences). In 2001, on the first of Wrights \& Sites' 'drifts' (destination-less, exploratory and experimental wanders), Cathy Turner, Stephen Hodge, Simon Persighetti and myself came across a massive and forbidding thicket of brambles within which the elegant shape of the red brick water tower, despite its size, could only be fuzzily made out. At first the brambles seemed impenetrable, but we eventually found tunnels through them and bent and crept, at the risk of ripping flesh and clothes on the thorns, to reach the structure and explore its outer passageways and pillars, 
It was one of the key 'finds' of our first 'drift', our first move away from theatrical product. The surprise and pleasure in finding such a beautiful thing, so dramatically concealed and revealing, confirmed our gamble on a theatre of the everyday, and within a few weeks Simon and I were re-visiting it with invited guests, one of whom based her PhD on the former Asylum which she visited for the first time that day.

The twists of the bramble tunnels were echoed in the curving passageway around the outside of the tower. This was not a labyrinth with a treasure or a monster at the middle of it; the whole thing, brambles and elegant brickwork, was the monstrous treasure. Here was the day's lesson: the inner was in the outer, the journey was not about, as Doreen Massey has worried, 'getting laddish thrills.... from rushing about down dark passages.... another form of eroticised colonisation of the city' (Massey 2005: 47) but about finding the labyrinth in the everyday, in the functional, in the interweaving of bramble and brick, in the accidental, in space that is under construction, always partly mysterious no matter how ordinary. As if to confirm the longevity of the effect of the redundant water tower, Wrights \& Sites would visit the tower once more, in 2007, celebrating the 10th anniversary of our first meeting. It was a shock to find the brambles gone, the ground around it neatly mown, and the whole thing now sited in the midst of a retail estate, beside KFC and Pizza Hut.

\section{Bodies in ruins}

When one is walking, the journey to, from and between ruins can generate an unexpected narrative and subject the body to both gentle impacts and extreme emotions, particularly when that walker is seeking to hypersensitize themselves to multiple factors: 'the impact of the unruly affordance of ruins on bodies, and the subsequent coercion of people into entanglements and performances.... disrupt normative understandings about what to do, promote scope for reflexive improvisation' (Edensor: 51). On foot in the ruins themselves the pull may be to the extreme: "pushing ourselves to our existential, embodied and emotional breaking points by sleeping in ruins for weeks on end.... searching for the most visceral connections to historic places' (Garrett 2013: 238). 
On a second visit to the water tower in 2001, Simon became trapped in the roof of the tower and was rescued with some difficulty. 14 years later I visited the same site on a walk between the three ruins discussed in this paper. Now sensitized by the framing performed by the windows of St Loye's chapel, visited barely half an hour before, I noticed, while inside the neighbouring KFC (it was Sunday lunchtime and low level family ritual eating of the chicken and drinking of the coke was underway), how the windows and signs of the fast food outlet ('MAKING EVERYDAY SPECIAL') were framing the water tower and the extensive belongings of a homeless person I had found there. Christmas decorations were still in evidence in the KFC and the scene was somewhat like the narrative of the 'Good King Wenceslas' carol.

I bought a 'Mighty Meal for One'. Eating it as I walked in the direction of the third set of ruins, the St Catherine's almshouses, I became nauseous and then embarrassed at my grouchy response when a woman joyously yelled at me: 'you're enjoying that!' In this moment of physical and social wobbliness I crested the brow of a hill and saw that the three ruins had played a trick on me. Though I had selected them quickly, simply to illustrate this paper's theme and with no thought for their location (I only realised when I began to write the paper that they were all in the same city), from the hill I saw that the three ruins all lay along the same ancient route, a surviving 'green lane' (Woodwater Lane) which passes the water tower on the outskirts of the city, then St Loye's chapel in the suburbs, in direct alignment with Heavitree church and its ancient yew, and then enters the old city from the South East, the route splitting at Livery Dole to take the walker to either the East or South Gates, equally spaced from St Catherine's. (A tower on the city wall drawn on the earliest published city map, by John Hooker in 1587, possibly indicates a more direct route and portal to the almshouses across the fields; which today's roads and footpaths now facilitate.)

The unfolding of this narrative was all the more potent (at least in the unfolding moment, for me, it was) because the yew (reputedly the descendent of much older trees that once marked the meeting place of the elders of the Dumnonii) and the Livery Dole (former execution site whose iron ring for chaining those burned to death was excavated there) were both places I had explored recently (November 2014) with choreographer Melanie Kloetzel (author of Site Dance, Kloetzel \& Pavlik) in developing the project inspired by the visit to St Loye's. 
After visiting the ruins of St Catherine's I continued my journey on the same trajectory. I walked under St Stephen's Bow (which requires the pedestrian to bend) and then, crossing the High Street, went in one end and came out the other end of the banking hall of Lloyd's Bank, and this saw me swiftly into Northernhay Gardens, the site of the most recent experiment with Melanie Kloetzel for the 'pseudo-sacred spaces' project.

The sites had created their own lineage for my work. They were telling my work through my walking body just as much as I was telling them through their stories and materials.

\section{$\underline{\text { Conclusion }}$}

In 2003, drawing on the experience of numerous 'drifts' with Wrights \& Sites, I described the potential use of ruins in, and as, a tactic of 'reverse archaeology': 'ruins on which the future can be built....metal rubbish, waste and dump can all be turned. Make your own statue.... Erect a monument to a fictional event' (Hodge et al 2003: 14). In naming the tactic I had in mind both the conventional understanding of 'reverse archaeology' (the returning of excavated artefacts to their sites of excavation) and, perhaps more importantly, the situationist tactic of détournement in which the original and constituent parts of a montage or mash up are intended to be ruined during the revivifying processes of hybridisation, juxtaposition and fragmentation.

What has changed since 2003, however, is that I now see ruins, even 'ruins', not as inert properties waiting for invasive or re-compositional acts, but as unfinished and vibrant matter which is already and always actively recomposing itself and, all the time, banging up against, hybridising with and ironically 'commenting on' other properties and actions. Informed by the writings of Jane Bennett, by my frustrations with ineffectual, moralistic and apocalyptic arguments around climate change that are all about human fault and discipline, and grudgingly coming to grasp the agency of materials as well as the shape and function of things while working with $3 D$ designer Polly Macpherson, I understand the agency of things as less an act of reenchanting on my part, than something I have finally woken up to. I understand now 
that the process of détourning ruins or reversing archaeology is one in which the walker-architects are themselves reversed and détourned, that the 'concrete matter.... [that] will always exceed the ambition and attempts to control and shape it' (Neilsen 2002: 54) not only 'exceeds' the attempts of those agents of power to curate, renovate, sign and maintain it, but, just as much, my own attempts to exploit and interpret it on my own terms.

When I wrote in my notebook 'Can this be utilised and developed? .... using fakery knowingly as 'another authenticity'?' or in 2003 how 'metal rubbish, waste and dump can all be turned', I had not yet fully understood how ruins are not passive, how the slope of the path into the Almshouses, the framing of the sky and modern houses, and the labyrinth of brambles can trip, map, highlight, transform, trap, threaten and lure. So, where in An Exeter Mis-Guide I had written about 'ruins on which the future can be built' I now understand that the ruins are already doing this. Their affordance is not their passivity but their capacity to 'confound the normative spacing of things, practices and people' (Edensor 2005: 18), to be our partners in creative ruination, in de- and re-composition, from the very beginnings of our projects.

By moving beyond, but also through, 'reverse archaeology' and détournement I have come to see ruins as vital and vibrant matter, materials always in transition, active and available, originators of projects, allies in defying attempts to tidy and restrain both them and us in physical restraints and restricted narratives; not things to be 'utilised' or 'built upon' but allies in slow revolution, in resistance to the hypervelocities of techno-linguistic automatisms and in 'disentangl[ing] the future.... from the traps of growth and investment.....in a new form of wisdom which harmonizes with exhaustion' (Berardi 2012: 80-1).

\section{REFERENCES}

Ahmed, Sara (2006) Queer Phenomenology, Durham, NC: Duke University Press. 
Berardi, Franco 'Bifo' (2012) The Uprising: on poetry and finance, Los Angeles: Semiotext(e).

Crabman \& Signpost (Phil Smith \& Simon Persighetti) (2012) A Sardine Street Box of Tricks, Axminster: Triarchy Press.

DeSilvey, Caitlin (2014) 'Palliative curation: art and entropy on Orford Ness' in Ruin Memories: Materiality, Aesthetics and the Archaeology of the Recent Past, Bjørnar Olsen \& Póra Pétursdóttir (eds), London \& New York: Routledge, pp.79-91.

Edensor, Tim (2005) Industrial Ruins, Oxford \& New York: Berg.

Garrett, Bradley L. (2013) Explore Everything: place-hacking the city, London \& New York: Verso.

Henare, Amiria, Martin Holbraad \& Sari Wastell (2007) 'Introduction: thinking through things' in Thinking Through Things: Theorising Artefacts Ethnographically, Amiria Henare, Martin Holbraad \& Sari Wastell (eds'), London \& New York: Routledge, pp.1-31.

Hodge, Stephen, Simon Persighetti, Phil Smith \& Cathy Turner (2003) An Exeter Mis-Guide, Exeter: Wrights \& Sites.

Kloetzel, Melanie \& Carolyn Pavlik (eds.) (2010) Site Dance: choreographers and the lure of alternative spaces, Gainesville (FL): University Press of Florida.

Massey, Doreen (2005) For Space, London: Sage Publications.

Mitchell, W. T. J. (2005) What Do Pictures Want? Chicago: University of Chicago Press.

Neilsen, Tom (2002) 'The return of the excessive: superfluous landscapes', Space and Culture, 5(1): 53-62.

Rendell, Jane (2011) 'Residues of a Dream World' in Gerrie Van Noord, (ed.), To Have And To Hold: future of a contested landscape, Edinburgh: Luath Press.

Sibley, David (1998) 'Purification of space', Environment and Planning D: Society and Space, 6. 409-21. 
Sterling, Bruce (2005) Shaping Things, Cambridge (Mass): The MIT Press. 